University of Nebraska - Lincoln

DigitalCommons@University of Nebraska - Lincoln

Determining soil erosion rates on semi-arid watersheds using radioisotope-derived sedimentation chronology

\author{
V. O. Polyakov \\ USDA-ARS, viktor.polyakov@ars.usda.gov
}

M. N. Nichols

USDA-ARS

M. A. Nearing

USDA-ARS, mark.nearing@ars.usda.gov

Follow this and additional works at: https://digitalcommons.unl.edu/usdaarsfacpub

Polyakov, V. O.; Nichols, M. N.; and Nearing, M. A., "Determining soil erosion rates on semi-arid watersheds using radioisotope-derived sedimentation chronology" (2017). Publications from USDA-ARS / UNL Faculty. 1794.

https://digitalcommons.unl.edu/usdaarsfacpub/1794

This Article is brought to you for free and open access by the U.S. Department of Agriculture: Agricultural Research Service, Lincoln, Nebraska at DigitalCommons@University of Nebraska - Lincoln. It has been accepted for inclusion in Publications from USDA-ARS / UNL Faculty by an authorized administrator of DigitalCommons@University of Nebraska - Lincoln. 


\title{
Determining soil erosion rates on semi-arid watersheds using radioisotope-derived sedimentation chronology
}

\author{
V. O. Polyakov, ${ }^{*}$ M. N. Nichols and M. A. Nearing \\ Southwest Watershed Research Center USDA-ARS, 2000 E. Allen Rd, Tucson, AZ 85719, USA
}

Received 25 April 2016; Revised 29 August 2016; Accepted 22 September 2016

*Correspondence to: Polyakov Viktor, Southwest Watershed Research Center USDA-ARS 2000 E. Allen Rd., Tucson, AZ 85719, USA. E-mail: viktor.polyakov@ars.usda. gov

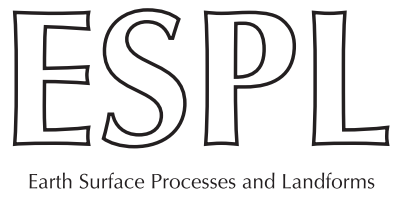

\begin{abstract}
This study investigates erosion dynamics of the past 90 years in three small semi-arid watersheds with histories of grazing and vegetation change. Activity of ${ }^{137} \mathrm{Cs}$ and excess ${ }^{210} \mathrm{~Pb}$ from 18 cores collected from sedimentation ponds were measured using a gamma spectrometer. The sediment was dated using a constant rate of supply (CRS) model. This study represents the first time that reservoir sediment accumulation rates determined from fallout isotopes have been verified by direct volumetric measurements of aggradation based on topographic surveys. Measured sedimentation in the ponds ranged between 1.9 and $2.3 \mathrm{~cm} \mathrm{y}$, representing average sediment delivery rates from the watersheds of between 0.6 and 2.0 tha $^{-1} \mathrm{y}^{-1}$. These sediment delivery rates were in agreement with those established by other methods for similar catchments in the region. Past variations in sedimentation rates were identified and correlated with recorded history of anthropogenic disturbance. ${ }^{137} \mathrm{Cs}$ and ${ }^{210} \mathrm{~Pb}$ methods are suitable for use in arid environments and can complement each other to increase reliability of erosion rate estimates. The abundance of stock ponds in southwestern USA presents an opportunity to quantify historic erosion and sediment transfer dynamics in areas that have not been well studied or instrumented. Published 2016. This article is a U.S. Government work and is in the public domain in the USA
\end{abstract}

KEYWORDS: soil erosion; sedimentation; lead-210; cesium-137; watershed; sediment chronology

\section{Introduction}

The semi-arid environment is characterized by high magnitude, low frequency rainfalls that produce highly variable soil erosion rates (Osterkamp and Friedman, 2000; Coppus and Imeson, 2002). Watersheds in this environment typically have well developed channel networks with complex storage and transport mechanisms. The relatively few sediment-producing runoff events may result in relatively low average annual sediment yields (Cohen and Laronne, 2005) which are difficult to estimate without long-term observations (Nearing et al., 2007; Polyakov et al., 2010a). Scarcity of data on erosion rates and the nature of watershed storage and delivery processes impede soil conservation decision making.

Sediments stored in depressions contain a record of long-term landscape erosion as well as evidence of major natural and anthropogenic disturbances. Accurate sediment chronologies are critical for interpreting these records. In the southwestern United States stock ponds are commonly constructed on rangelands to harvest water for irrigation, livestock, and flood control. These ponds present a unique opportunity for measuring sediment accumulation and erosion rates on contributing watersheds. Until now this was accomplished on selected locations through long-term repetitive topographic surveys of aggradation (Nichols, 2006). In this work we aimed at expanding the tools available for this purpose by applying isotopic chronostratigraphic techniques to small artificial rangeland ponds.

An isotope of lead ${ }^{210} \mathrm{~Pb}$ (half-life 22.3 years) is commonly used for dating recent sediment. It originates from the decay of ${ }^{226} \mathrm{Ra}$ through short lived gaseous ${ }^{222} \mathrm{Rn}$ (half-life 3.8 days). In a closed system ${ }^{210} \mathrm{~Pb}$ remains in equilibrium with its in situ ${ }^{226} \mathrm{Ra}$ source and is called 'supported'. ${ }^{210} \mathrm{~Pb}$ produced from ${ }^{222} \mathrm{Rn}$ that escapes into the atmosphere and precipitates to the Earth surface is referred to as 'excess'. Therefore, the soil surface and more recent sediments exposed to atmospheric fallout typically contain elevated amounts of ${ }^{210} \mathrm{~Pb}$. When sediments are buried by new material the excess lead $\left({ }^{210} \mathrm{~Pb}_{\mathrm{ex}}\right)$ in those sediments is no longer replenished from the atmosphere and decays over time, which reflects the age of the buried deposit.

A variety of conversion models that derive sediment age from radiometric data are based on a basic equation formulated by Krishnaswami et al. (1971) that relates sedimentation rate with ${ }^{210} \mathrm{~Pb}$ activity at the point of interest, its excess flux, and isotope decay rate. Among the most commonly used forms of the equation are constant initial concentration $(\mathrm{CIC})$, constant flux constant sedimentation (CFCS) (Appleby, 1998, 2008), and sediment isotope tomography (SIT) models (Carroll et al., 1999). Mixing and re-deposition of sediment due to hydrological or biological processes or changes in sediment supply might violate some of the model's assumptions. Hence the dates need 
to be validated whenever possible by independent age markers (Appleby, 2001).

${ }^{210} \mathrm{~Pb}$ has been successfully used to determine the age of recent (100 years) deposits in a variety of marine (Carroll et al., 1999; Alvarez-Iglesias et al., 2007; Van Eaton et al., 2010), lacustrine (Turner and Delorme, 1996; Appleby, 2001), and flood plain (Terry et al., 2011; Aalto and Nittrouer, 2012) environments. The method has proved to be useful in providing information on erosion rates and its historic variability on watersheds contributing to reservoirs (Wren and Davidson, 2011) and is applicable across a wide range of watershed sizes $\left(12\right.$ and $\left.5 \times 10^{7}\right)$ and precipitation regimes (340-2500 $\mathrm{mm} \mathrm{y}^{-1}$ ) (Appleby, 2008).

Arid environments present a challenge for the application of the method due to low rainfall resulting in reduced atmospheric ${ }^{210} \mathrm{~Pb}$ flux. However, the method was successfully used in desert lakes in Chile (Jenny et al., 2002), Egypt (Flower et al., 2006), and China (Liu et al., 2012). Accumulation rates as low as $5 \mathrm{~mm} \mathrm{y}^{-1}$ were measured. Sedimentation processes in arid stock ponds resemble those in lacustrine environments; however, accumulation of sediment is intermittent, seasonal, and defined by episodic flood events. The ${ }^{210} \mathrm{~Pb}$ fallout is also sporadic due to monsoon climate and occasional high rainfall years. These challenges, however, may be addressed by the use of independent age markers such as ${ }^{137} \mathrm{Cs}$ (Appleby, 1997; Kirchner, 2011) alongside ${ }^{210} \mathrm{~Pb}$ measurements.

The objectives of the study were to: (a) investigate the applicability of fallout isotope method for chronostratigrapgy in small, monitored semi-arid ponds; (b) estimate historic soil erosion and sedimentation rates on selected watersheds; (c) determine the effect of management and hydrologic regime on the sedimentation and erosion processes. This study is the first to apply this method to reservoirs that have been monitored long-term for runoff and sediment accumulation.

\section{Methods}

\section{Location and watershed characteristics}

Three watersheds selected for the study were located on the Walnut Gulch Experimental Watershed (WGEW), which is a part of upper San Pedro River basin in southeastern Arizona, USA (Figure 1). The climate in the area is semi-arid, dominated by North American Monsoon (Sheppard et al., 2002) with annual precipitation of $270 \mathrm{~mm} \mathrm{y}^{-1}$ (Table I). The precipitation is highly spatially and temporally variable with a pronounced peak in July through mid-September, which accounts for $60 \%$ of annual rainfall. Mean daily temperatures are $24{ }^{\circ} \mathrm{C}$ in July and $10^{\circ} \mathrm{C}$ in January.

The soils on watersheds were formed on alluvial fans and are characterized by shallow A horizon underlain by deep argillic and calcic horizon. Vegetation is dominated by whitethorn acacia, creosote bush, tarbush, black grama, and curly mesquite.

Each of the three watersheds, numbered 201, 208, and 214, drains into a stock pond with the same number. Stock ponds are excavated across the main drainage channel and contained by an earthen dam with spillway. Water depth in the ponds is monitored using a stilling well equipped with a float and water level recorder. Sediment accumulation was measured through periodic topographic surveys of the surface of each stock pond when the ponds were dry. This allowed accurate monitoring of the trapped sediment volume change. Sediment lost through spillway was estimated from stage records via standard weir formula, and concentration estimated from depth integrated sampler. For details about these measurements, their analysis, and pond instrumentation see Nichols (2006) and Nichols et al. (2014). Three automated rain gages are located in close proximity to ponds.

The watersheds are under continuous grazing, although its intensity is not documented. In June 1971, brush was removed from Watershed 201 and the watershed was seeded to Bouteioua curtipendula and gracilis. However, mesquite, whitethorn and creosote bush have since re-established throughout the treated area. Sediment dredging was conducted in pond 201 in 1966 and 1969 totaling $330 \mathrm{~m}^{3}$. However, the spatial distribution of this operation as well as the fate of the dredged sediment were not documented.

\section{Sample collection and isotope analysis}

Profile samples were collected in May-July 2014. One transect was laid out across the middle of each pond. An access trench

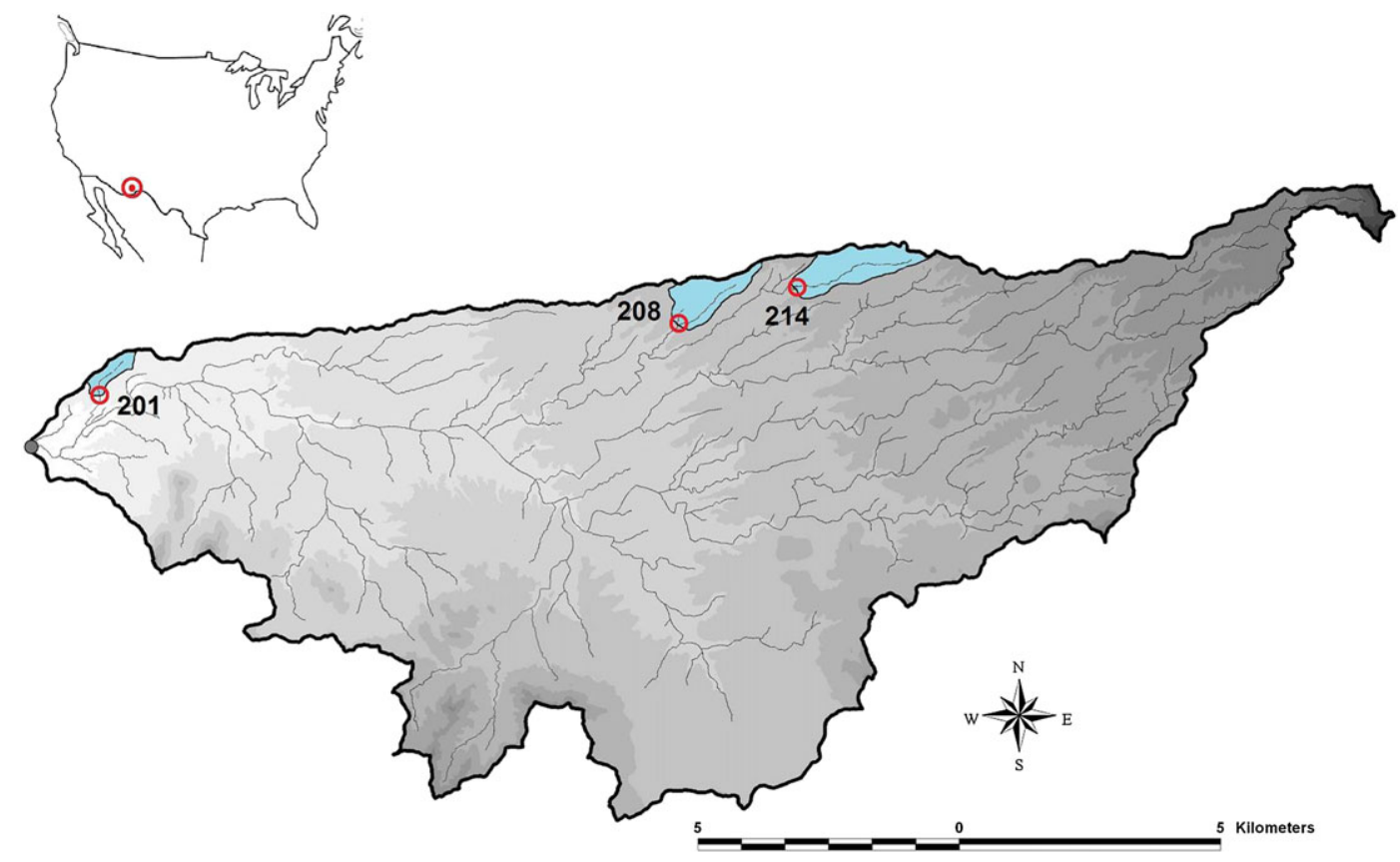

Figure 1. Location of the study sites on Walnut Gulch Experimental Watershed. [Colour figure can be viewed at wileyonlinelibrary.com] 
Table I. Watershed and stock pond characteristics (Nichols, 2006 unless otherwise indicated).

\begin{tabular}{|c|c|c|c|}
\hline Stock pond / watershed ID & 201 & 208 & 214 \\
\hline Average annual precipitation, $\mathrm{mm}$ & 277 & 269 & 277 \\
\hline Watershed area, ha & 44.0 & 92.2 & 150.5 \\
\hline Elevation at pond, m & 1252 & 1400 & 1441 \\
\hline Average channel slope & 0.021 & 0.026 & 0.019 \\
\hline Soil texture & gravelly sandy loam & gravelly fine sandy loam & very gravelly loam \\
\hline Soil series ${ }^{1}$ & Luckyhills McNeal & McAllister-Stronghold & Stronghold-Bernardino \\
\hline Sediment record start & 1967 & 1973 & 1957 \\
\hline Average runoff, $\mathrm{mm} \mathrm{y}^{-1}$ & 11.0 & 13.4 & 16.8 \\
\hline Pond capacity in $2004, \mathrm{~m}^{3}$ & 5300 & 7600 & 17900 \\
\hline Sediment accumulation (from record start), $\mathrm{m}^{3}$ & 870 & 1090 & 11015 \\
\hline Trap efficiency, \% & 90.5 & 76.1 & 92.2 \\
\hline Sediment yield (survey), $\mathrm{t} \mathrm{ha}^{-1} \mathrm{y}^{-1}$ & 0.9 & 0.6 & 2.1 \\
\hline Sediment yield ${ }^{2}$, h ha $^{-1} \mathrm{y}^{-1}$ & 0.8 & 0.8 & 2.3 \\
\hline
\end{tabular}

${ }^{1}$ NRCS (2003), ${ }^{2}$ Lane et al. (1997)

was excavated along each transect to the depth of 1.5 to $3 \mathrm{~m}$ all the way through the depositional layer, as approximately identified by color and texture.

The samples were collected from the wall of the trench along vertical profile at $15 \mathrm{~cm}$ depth increments. Individual profiles were located along the trench 3 to $5 \mathrm{~m}$ apart depending on the pond. Seven profiles were sampled on watershed 201, six on 208, and five on 214, with a total of 237 samples (Table I). Sediment samples were dried and ground to $<2 \mathrm{~mm}$ fraction, placed into $170 \mathrm{~mL}$ polypropylene jars with air-tight lid, and incubated for $>25$ days to achieve secular equilibrium in the ${ }^{226} \mathrm{Ra}-{ }^{210} \mathrm{~Pb}$ decay chain.

The analyses for ${ }^{137} \mathrm{Cs}$ and ${ }^{210} \mathrm{~Pb}$ was performed at the Southwest Watershed Research Center using a gamma ray spectrometry system consisting of two high-purity germanium detectors (Canberra BE5030) with $>30 \%$ relative efficiency and multi-channel analyzer (Lynx). The detectors were enclosed in $100 \mathrm{~mm}$ thick lead shields. The system was calibrated using mixed radionuclide reference material IAEA-447 (Shakhashiro et al., 2012) certified by the International Atomic Energy Agency. The gamma emission spectrum was obtained over 0-2 MeV range with resolution of $0.24 \mathrm{keV}$ (8192 channels). Measurement and spectrum analysis was conducted using Genie-2000 Spectroscopy software (Canberra, 2009). The samples were counted for at least $160000 \mathrm{~s}$ or until $<5 \%$ peak area uncertainty was achieved. Activity of ${ }^{137} \mathrm{Cs}$ was calculated directly from the $661.6 \mathrm{keV}$ photopeak and ${ }^{210} \mathrm{~Pb}_{\text {ex }}$ was calculated as the difference between ${ }^{210} \mathrm{~Pb}_{\text {total }}$ and ${ }^{214} \mathrm{~Pb}$ at equilibrium. Background gamma activity was determined using container blanks. The analysis included correction for self-attenuation due to variation of sample density (Quindos et al., 2006).

\section{Calculation of sedimentation and erosion rates}

Due to non-monotonic variation of the ${ }^{210} \mathrm{~Pb}_{\mathrm{ex}}$ concentration with depth, we chose to use the CRS (constant rate of supply) conversion model (Appleby and Oldfield, 1978) to determine sediment accumulation rates in the ponds:

$$
t_{i}=\frac{1}{\lambda} \ln \left(\frac{A(0)}{A_{i}}\right)
$$

where $t_{i}$ is the age of sediment at depth $i, \lambda$ is radioactive decay constant of ${ }^{210} \mathrm{~Pb}\left(0.03114 \mathrm{y}^{-1}\right)$, and $A(0)$ and $A_{i}$ are unsupported ${ }^{210} \mathrm{~Pb}$ inventory at depth 0 and $i$, respectively.
The CRS model is based on the following assumptions: (a) the rate of deposition of ${ }^{210} \mathrm{~Pb}_{\text {ex }}$ from the atmosphere is constant; (b) ${ }^{210} \mathrm{~Pb}_{\mathrm{ex}}$ is quickly adsorbed to particulate matter; and (c) the initial concentration in any sediment layer will thus vary in inverse proportion to the sedimentation rate. The CRS model has been tested and validated in lakes with variable accumulation rates with good results (Turner and Delorme, 1996; Appleby, 2008; Ahn et al., 2010).

Accuracy of sediment dating by the CRS model, particularly deeper layers, is greatly influenced by the estimate of total inventory $A(0)$ obtained via integration of the ${ }^{210} \mathrm{~Pb}$ profile. Although the exact date of stock ponds construction is unknown, it is less than 90 years (approximately $4.5{ }^{210} \mathrm{~Pb}$ half-lives). This means that ${ }^{210} \mathrm{~Pb}$ concentration at the lowest sediment layer just above the original (excavated) bottom of the pond is not at equilibrium constituting a case of incomplete inventory. To correct $A(0)$ a reference depth for each profile was determined from ${ }^{137} \mathrm{Cs}$ peak depth, which corresponds to 1963. The ${ }^{210} \mathrm{~Pb}$ inventory below that depth was calculated as:

$$
A_{i}=\frac{\Delta A}{e^{t_{i} \lambda}-1}
$$

where $\Delta A$ is ${ }^{210} \mathrm{~Pb}$ ex inventory above depth $i$, and $t_{i}$ is the age of the reference level.

\section{Results and discussion}

\section{Radionuclide activity profiles and inventories}

Figures 2 and 3 show ${ }^{137} \mathrm{Cs}$ and excess ${ }^{210} \mathrm{~Pb}$ activity in selected sediment profiles from the three ponds. All of the profiles (except 201-1) had a characteristic steady increase of ${ }^{137} \mathrm{Cs}$ activity with depth and a pronounced peak followed by sharp decline below. Profile 201-1 was sampled only to the peak depth and ${ }^{137} \mathrm{Cs}$ behavior below that depth was not identified.

In the absence of physical disturbance peak ${ }^{137} \mathrm{Cs}$ activity in deposits corresponds to 1963, which is the year of its maximum atmospheric fallout, while the deepest point with detectable activity corresponds to 1954, which is the beginning of atmospheric fallout. The diffusion and downward migration of ${ }^{137} \mathrm{Cs}$ through the profile has reported convection velocities of 0 to $3.5 \mathrm{~mm} \mathrm{y}^{-1}$ (Likar et al., 2001; Almgren and Isaksson, 2006; Legarda et al., 2011) and is very slow in comparison with observed annual sedimentation rates. Hence, severe 


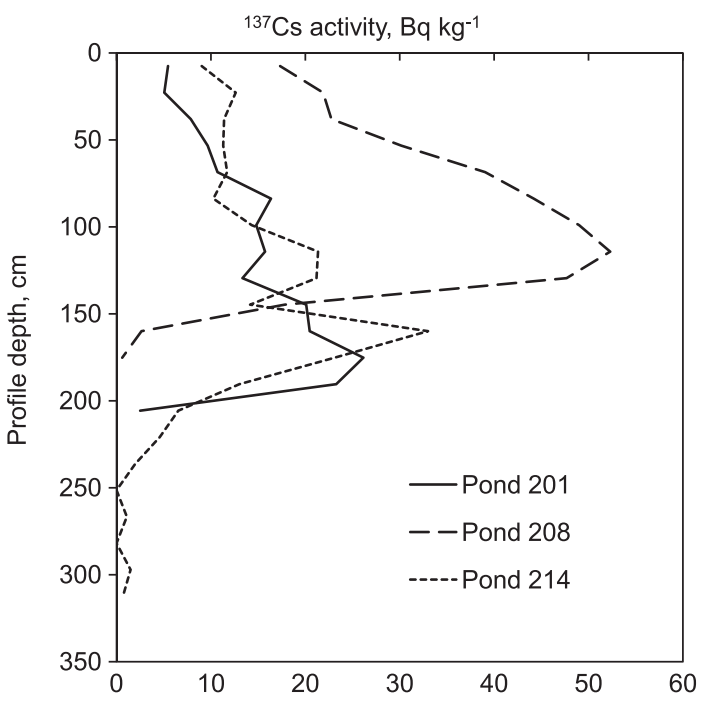

Figure 2. Distribution of ${ }^{137} \mathrm{Cs}$ in sediments in the central (deepest) profile of the ponds.

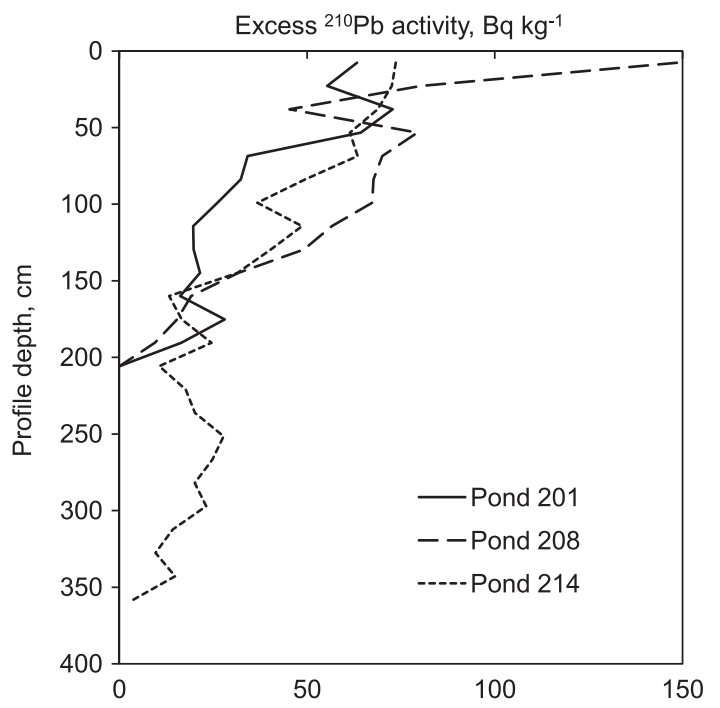

Figure 3. Distribution of ${ }^{210} \mathrm{~Pb}_{\mathrm{ex}}$ in sediments in the central (deepest) profile of the ponds.

overestimation of the deposition time using this chronological marker is unlikely.

At all locations ${ }^{137} \mathrm{Cs}$ peak was deeper in the middle of the pond $(130 \mathrm{~cm}$ in 208 and $170 \mathrm{~cm}$ in 201 and 214) and shallower in the periphery, suggesting a lens-like depositional pattern with sediment layer tapering towards the edges. Pond 208 showed the greatest ${ }^{137} \mathrm{Cs}$ activity at peak $\left(53 \mathrm{~Bq} \mathrm{~kg}^{-1}\right)$, approximately twice as high as in 201 and 214 (26 and $33 \mathrm{~Bq} \mathrm{~kg}^{-1}$, respectively). The total ${ }^{137} \mathrm{Cs}$ inventory for ponds 201, 208, and 214 were 26,100, 54,300, and $41900 \mathrm{~Bq} \mathrm{~m}^{-2}$.

High peak concentration of ${ }^{137} \mathrm{Cs}$ and its shallow location in 208 suggests domination of sheet processes and lower erosion rates in comparison with the other two watersheds. Upon the fallout the very surface of the soil containing elevated level of nuclide was eroded without being diluted with underlying material. Further, this difference could have been amplified by the fact that watershed 208 has the finest soil (fine sandy loam) among the three locations, which enables better adsorption and increased nuclide retention (Li et al., 2004).

The activities of ${ }^{210} \mathrm{~Pb}_{\mathrm{ex}}$ in all profiles overall steadily declined with depth (Figure 3). Some deviation from exponential decline curve was observed. This is indicative of variable deposition rate accompanied by either dilution or concentration of nuclide in sediments. High activities indicate low accumulation rate periods and vice versa (Appleby, 2008). Considering the small size of the ponds and seasonal, flashflood type of hydrological regime of the contributing watersheds such deposition behavior is very likely. In addition, some of the variability could be attributed to physical or biological mixing of sediment layers.

The maximum ${ }^{210} \mathrm{~Pb}_{\text {ex }}$ activity in most cases was found in the surface sediment layer with values varying between 63 and $96 \mathrm{~Bq} \mathrm{~kg}^{-1}$ in ponds 201 and 214, and between 110 and $154 \mathrm{~Bq} \mathrm{~kg}^{-1}$ in pond 208. Detectable ${ }^{210} \mathrm{~Pb}_{\text {ex }}$ was found at greater depths in profiles near the center of ponds than in peripheral locations, a spatial pattern similar to that exhibited by ${ }^{137} \mathrm{Cs}$.

The ${ }^{210} \mathrm{~Pb}$ activity in the deepest samples in 201 and 208 was near secular equilibrium with ${ }^{226} \mathrm{Ra}$. Considering that the age of the ponds is approximately $4{ }^{210} \mathrm{~Pb}$ half-lives, these bottom samples were extracted from the original (old) alluvium. In pond 214, however, the deepest samples contained between 4 and $27 \mathrm{~Bq} \mathrm{~kg}^{-1}$ of ${ }^{210} \mathrm{~Pb}_{\mathrm{ex}}$, indicating either incomplete profile sampling or a considerable degree of perturbation in the early years of deposition. Total ${ }^{210} \mathrm{~Pb}_{\mathrm{ex}}$ inventory for ponds 201, 208, and 214 were 58 700, 135 200, and $115800 \mathrm{Bqm}^{-2}$.

\section{Sedimentation chronology}

Ponds 201 and 208 were not identifiable landscape features on 1935 aerial photos and most likely were built in the late 1930s. Pond 214 was constructed around 1918 (ADWR, 2015) and is present on 1935 aerial photos. Its documented age is corroborated by ${ }^{210} \mathrm{~Pb}_{\mathrm{ex}}$ found at depths well beyond the depth of $1963{ }^{137}$ Cs peak (Figure 3 ).

The overall non-monotonic ${ }^{210} \mathrm{~Pb}$ concentration pattern in most of the profiles (Figure 3 ) as described in previous section suggested use of the CRS model for sediment dating. The anticipated maximum age of pond deposits required correction of ${ }^{210} \mathrm{~Pb}_{\mathrm{ex}}$ chronology with an independent age marker ${ }^{137} \mathrm{Cs}$. The CRS model without correction for incomplete inventory was found to have overestimated sediment age for older deposits, in addition, the overestimation increased with depth (Appleby, 2008). The first appearance of ${ }^{137} \mathrm{Cs}$ in the deposition profile corresponds to 1954 . Nuclide activity of ${ }^{137} \mathrm{Cs}$ at this depth was very low, close to the detection limit; hence a more reliable age reference was ${ }^{137} \mathrm{Cs}$ peak concentration corresponding to 1963.

The estimated age of the sediments across the transects in ponds 201, 208, and 214 is shown in Figure 4. All three ponds exhibited lens-like deposition patterns, greater in the center and tapering towards the periphery. While in ponds 208, 214 the isochrones are continuous with older deposits located in the middle, pond 201 exhibits some perturbations. Its central deeper area ( 9 to $12 \mathrm{~m}$ of the transect) lacks sediments from 1935-1955 (Figure 4(A)). This is despite the fact that sampled profiles penetrated through the entire deposition layer to the parent material, as is evident from both isotopic analysis and physical characteristics of the samples. At the same time there was an accumulation of similarly aged material (1960-1970) observed at $24 \mathrm{~m}$ of the transect (Figure 4(A)). This anomaly could be attributed to pond dredging efforts conducted in 1966 and 1969. It is likely that early sediments were not removed or partially removed from the pond and were instead pushed to the pond boundary and mixed in the process. Consequently all were covered by newer deposits. 

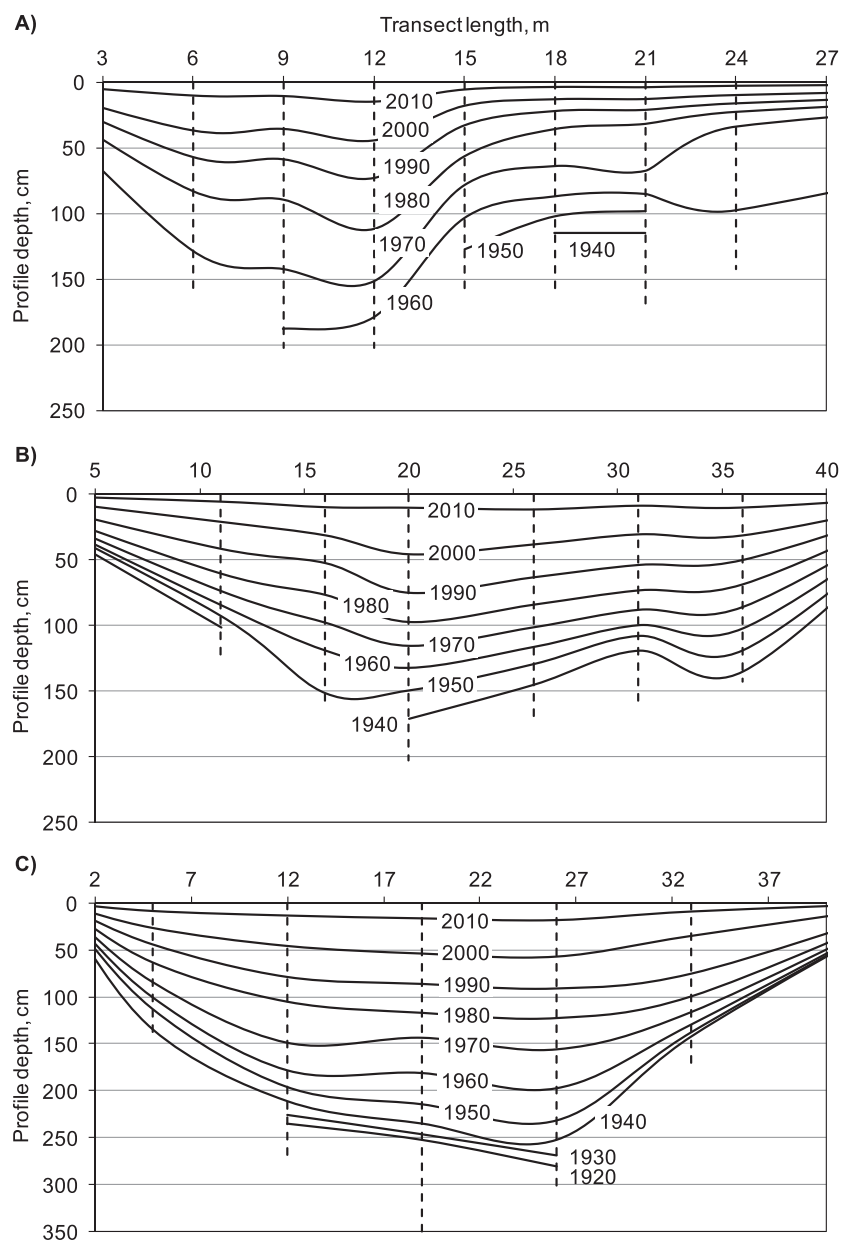

Figure 4. Age of the sediments along the transects in ponds 201 (A), 208 (B), and 214 (C). Dashed line represents the location and maximum depth of sampled profiles.

\section{Sediment accumulation and watershed erosion rates}

The average sediment accumulation rates over the period analyzed were $2.1,1.9$, and $2.3 \mathrm{~mm} \mathrm{y}^{-1}$ for ponds 201, 208, and 214, respectively (Table II). This translates into long-term average sediment yield of $0.89,0.57$, and $1.99 \mathrm{tha}^{-1} \mathrm{y}^{-1}$ on the corresponding watersheds based on the size of the ponds and sediment densities. These values compare well with the

Table II. Estimated sediment accumulation in the stock ponds and sediment yield from the contributing watersheds based on isotopic analysis.

\begin{tabular}{|c|c|c|c|}
\hline Pond ID & 201 & 208 & 214 \\
\hline Accumulation period & 1935-2014 & 1935-2014 & 1918-2014 \\
\hline $\begin{array}{l}\text { Accumulated sediment } \\
\text { volume, } \mathrm{m}^{3}\end{array}$ & 2190 & 2470 & 20280 \\
\hline $\begin{array}{l}\text { Trap efficiency } \\
\text { (Nichols, 2006) }\end{array}$ & 0.91 & 0.76 & 0.92 \\
\hline $\begin{array}{l}\text { Total sediment } \\
\text { volume, } \mathrm{m}^{3}\end{array}$ & 2420 & 3250 & 20340 \\
\hline \multicolumn{4}{|c|}{ Pond average sedimentation rate, $\mathrm{cm} \mathrm{y}^{-1}$} \\
\hline average & 2.1 & 1.9 & 2.3 \\
\hline maximum & 3.8 & 2.4 & 3.3 \\
\hline minimum & 1.1 & 1.3 & 0.8 \\
\hline $\begin{array}{l}\text { Watershed sediment } \\
\text { yield, } \mathrm{tha}^{-1} \mathrm{y}^{-1}\end{array}$ & 0.89 & 0.57 & 1.99 \\
\hline
\end{tabular}

rates (Table I) obtained by direct topographic measurements of the ponds (Nichols, 2006) and other methods (Lane et al., 1997). They are also within the range of values (0.06 to $5.7 \mathrm{tha}^{-1} \mathrm{y}^{-1}$ ) reported for small watersheds in the area (Lane et al., 1997; Lane and Kidwell, 2003; Nearing et al., 2007).

All ponds showed different deposition rate behavior during the observation period. Pond 201 exhibited a sharp increase (94\%) in sedimentation rate between 1960 and 1980, followed by a decrease to the initial rate of $1.6 \mathrm{~cm} \mathrm{y}^{-1}$ (Figure 5). There wasn't an increase in rainfall or runoff (Figure 6) during 1960-1980 that would explain such dramatic changes in sedimentation rate. It is plausible that this deposition peak is associated with the brush treatment. While mesquite removal typically leads to reestablishment of grasses and erosion mitigation (Osborn et al., 1978; Martin and Morton, 1993; Lane and Kidwell, 2003) the removal process itself is very intrusive and might have initially dislodged a large amount of sediment.

Sediment displaced by rainfall is characterized by residence time on the watershed. This residence time is variable and can be significant. Channel networks in arid watersheds have large storage capacity for the eroded material that increases in the downstream direction, in part due to transmission losses and reduction of flow as the water moves downstream (Osterkamp and Toy, 1997). This material can remain intact within a watershed for extended periods of time (Nichols, 2006) and then be released during future flow events (Polyakov et al., $2010 b)$. As a result large rainfall events or a wet year may not necessarily produce immediate sedimentation peak in the stock pond. The sedimentation rate in pond 208 remained relatively steady, increasing from $1.5 \mathrm{~cm} \mathrm{y}^{-1}$ in 1940 to $2.3 \mathrm{~cm} \mathrm{y}^{-1}$ in 2014, while pond 214, the largest among the three, showed steady increase from $0.6 \mathrm{~cm} \mathrm{y}^{-1}$ in 1918 to $3.2 \mathrm{~cm} \mathrm{y}^{-1}$ in 2014 (Figure 5).

Nichols (2006) studied the same ponds and reported a significant relationship between runoff and sediment yield for watershed 208, and lack of this relationship for watersheds 201 and 214. In our investigation relationships between sedimentation and runoff or precipitation could not be established. This might be partially due to the integrative nature of profile sampling. A single $15 \mathrm{~cm}$ increment combined sediments deposited during several (3 to 10) years and an even greater number of runoff events. Hence, high yield years were

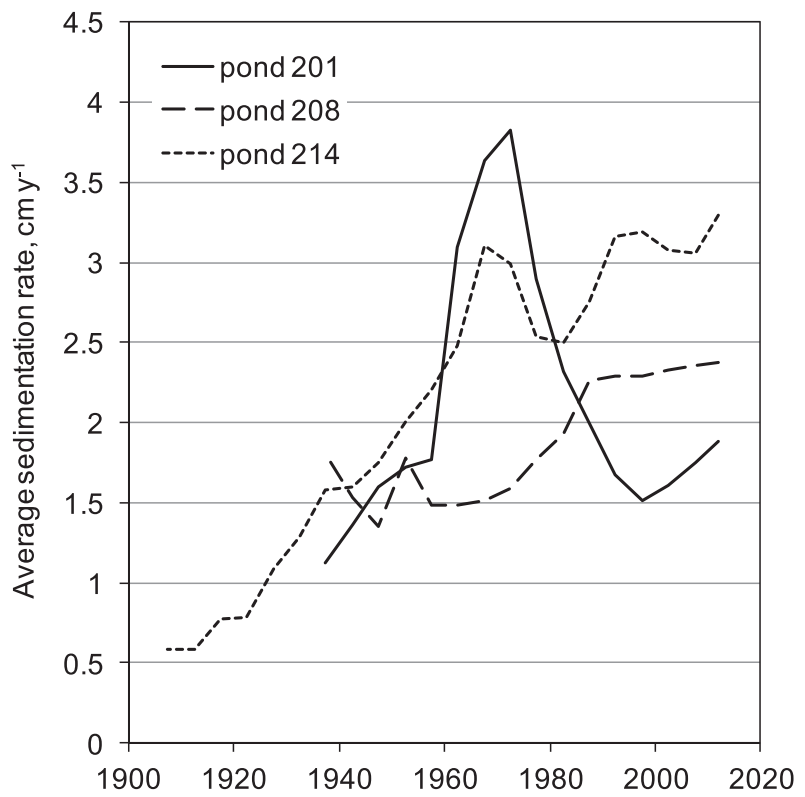

Figure 5. Sedimentation rate dynamics on watersheds 201,208 , and 214 during the observed period. 


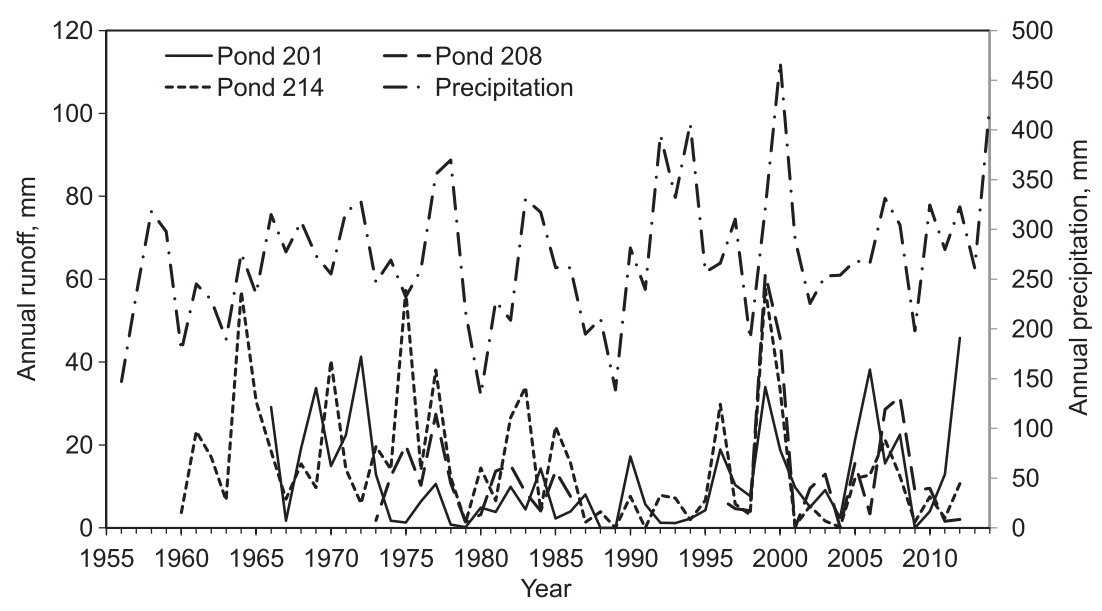

Figure 6. Precipitation and runoff on watersheds 201, 208, and 214. Runoff data for watershed 208 between 1986 and 1996 is not available.

averaged with low yield years, potentially masking the effect of large events. In addition, the channel transport system has buffering capacity, deposition is driven by biological perturbations and sediment focusing caused by multiple channel entry points into the ponds. As a result, under current pond management and sampling approach only multiyear trends could be identified.

A number of large runoff events (or close sequence of events) resulted in pond spillover causing underestimation of sedimentation rate. In contrast, small runoff events were captured entirely with all sediment volume being retained. During the rainy season the pond is more likely to overflow due to relatively large storm size and higher frequency (pond being partially filled from preceding events). Hence, trapping efficiency has two overlapping trends. It decreases over the long term due to reservoir fillup, and it is effectively higher during winter storms and lower during monsoon season. Although in our case spillover losses were accounted for, care should be taken when applying isotope-derived sediment chronology on non-instrumented stock ponds. Long-term sedimentation patterns suggest that sediment yields were not entirely related to historical rainfall or runoff trends (Figure 6). There may be a complex interaction that involved long-term plant cover changes, soil degradation, and evolution of channel networks. Further research that includes measures of the size and density of the drainage system in each watershed, and vegetation and grazing history as well as watershed-wide isotopic sampling are needed to help further interpret deposition patterns.

\section{Conclusion}

In this study erosion and sedimentation rates in three artificial ponds fed by small watersheds were determined using isotopes ${ }^{210} \mathrm{~Pb}$ and ${ }^{137} \mathrm{Cs}$. This is the first time the results of isotopic analysis of sediment profiles in arid reservoirs were compared with direct repetitive measurements of aggradation. The top $15 \mathrm{~cm}$ of sediment in the studied ponds contained between 63 and $154 \mathrm{~Bq} \mathrm{~kg}^{-1}$ of ${ }^{210} \mathrm{~Pb}_{\mathrm{ex}}$. Its activity steadily declined with depth in all profiles. Both the overall level and distribution trend of ${ }^{210} \mathrm{~Pb}_{\mathrm{ex}}$ indicated good potential for isotopic chronostratigraphy. Observed deviation of the concentration profile from the exponential distribution curve was indicative of the environment with intermittent, flood driven depositional processes.

Due to the relatively short total age of accumulation in at least two of the ponds (201 and 208) ${ }^{210} \mathrm{~Pb}_{\mathrm{ex}}$ profiles were incomplete. This is a common feature of recently constructed (less than 3 to $4{ }^{210} \mathrm{~Pb}$ half-lives) artificial reservoirs. Hence a remedial technique, namely, the use of an independent age marker, was employed. ${ }^{137}$ Cs proved to be a reliable tool for this purpose. It had clearly identifiable starts and peaks of accumulation corresponding to 1954 and 1963, respectively, and was present in all profiles in concentrations sufficient for reliable analysis.

A Constant Rate of Supply model was used to convert ${ }^{210} \mathrm{~Pb}_{\text {ex }}$ activity from 237 samples in 18 vertical profiles and three transects into sedimentation rates. The mean sedimentation rates ranged from 0.8 to $3.8 \mathrm{~cm} \mathrm{y}^{-1}$ and compared well with data obtained from topographic surveys (Nichols, 2006). These rates translate to sediment yields of 0.9, 0.6, and 2.0 tha $^{-1} \mathrm{y}^{-1}$ on watersheds 208,201 , and 214 , respectively, which is consistent with values obtained on instrumented watersheds of similar size in WGEW (Nearing et al., 2007). Sedimentation rates varied greatly over short distances (several meters) with more deposition occurring in the central (initially deeper) area of the ponds. The differences between adjacent profiles located just 4 to $7 \mathrm{~m}$ apart highlight the importance of extensive sampling (obtaining multiple profile) to characterize a reservoir. In our study sampled profiles were located along single transects. Considering the observed spatial variability, a grid pattern may provide better quantification of the sedimentation process. This approach, however, is limited by the time and cost of the isotopic analysis.

Documented management practices such as mesquite treatment and dredging (pond 201), as well as long-term trends could be identified in the chronosequence. Short-term (single event or seasonal) deposition increases that might have occurred could not be resolved given our sampling intensity of approximately 5 years of deposition per sample. In addition, biological perturbations (mixing by the hoof action of cattle) would have lessened those peaks. Greater vertical sampling resolution is necessary to resolve such variations.

Overall ${ }^{210} \mathrm{~Pb}$ technique can be a useful tool for estimation of erosion rates on small arid watersheds with ponds if the latter satisfy criteria such as good trapping efficiency, minimal disturbance and sufficient amount of accumulated sediment. There are $>28000$ stock ponds in Arizona alone, hence providing a huge potential to estimate historic erosion dynamics in areas that have not been well studied or instrumented.

Acknowledgments - The authors wish to express their appreciation to the Southwest Watershed Research Center staff, particularly M. Cavanaugh, J. Smith, and K. Heintz, whose dedicated efforts in collecting data made this research possible. The USDA is an Equal Opportunity Employer. 


\section{References}

Aalto R, Nittrouer CA. 2012. Pb-210 geochronology of flood events in large tropical river systems. Philosophical Transactions of the Royal Society A - Mathematical Physical and Engineering Sciences 370(1966): 2040-2074.

ADWR. 2015. Surface water data. Arizona Department of Water Resources.

Ahn YS, Nakamura F, Chun KW. 2010. Recent history of sediment dynamics in Lake Toro and applicability of Pb-210 dating in a highly disturbed catchment in northern Japan. Geomorphology 114(3): 284-293

Almgren S, Isaksson M. 2006. Vertical migration studies of Cs-137 from nuclear weapons fallout and the Chernobyl accident. Journal of Environmental Radioactivity 91(1-2): 90-102.

Alvarez-Iglesias P, Quintana B, Rubio B, Perez-Arlucea M. 2007. Sedimentation rates and trace metal input history in intertidal sediments from San Simon Bay (Ria de Vigo, NW Spain) derived from $\mathrm{Pb}-210$ and (CS)-C-137 chronology. Journal of Environmental Radioactivity 98(3): 229-250.

Appleby PG. 1997. The use of Pb-210 and Cs-137 as tracers in modelling transport processes in lake catchment systems. In Freshwater and Estuarine Radioecology, Desmet G et al. (eds). Studies in Environmental Science. Elsevier Science Bv: Amsterdam; 441-448.

Appleby PG. 1998. Dating recent sediments by $210 \mathrm{~Pb}$ : problems and solutions. In Dating of Sediments and Determination of Sedimentation, Illus RE (ed) : Finland; 7-24.STUK A-145

Appleby PG. 2001. Chronostratigraphic techniques in recent sediments. In Tracking Enivironmental Change using Lake Sediments: Basin Analysis, Coring, and Chronological Techniques, Last WM, Smol JP (eds). Kluwer Academic Publishers: Dordrecht; 171-203.

Appleby PG. 2008. Three decades of dating recent sediments by fallout radionuclides: a review. Holocene 18(1): 83-93.

Appleby PG, Oldfield F. 1978. The calculation of Lead-210 dates assuming a constant rate of supply of unsupported $210 \mathrm{~Pb}$ to the sediment. Catena 5: 1-8.

Canberra. 2009. Genie-2000 v3.2 Operations Manual. Canberra Industries Inc., Meriden, CT.

Carroll J, Lerche I, Abraham JD, Cisar DJ. 1999. Sediment ages and flux variations from depth profiles of $\mathrm{Pb}-210$ : lake and marine examples. Applied Radiation and Isotopes 50(4): 793-804.

Cohen H, Laronne JB. 2005. High rates of sediment transport by flashfloods in the Southern Judean Desert, Israel. Hydrological Processes 19(8): 1687-1702.

Coppus R, Imeson AC. 2002. Extreme events controlling erosion and sediment transport in a semi-arid sub-andean valley. Earth Surface Processes and Landforms 27(13): 1365-1375.

Flower RJ et al. 2006. Environmental changes at the desert margin: an assessment of recent paleolimnological records in Lake Qarun, Middle Egypt. Journal of Paleolimnology 35(1): 1-24.

Jenny B et al. 2002. Moisture changes and fluctuations of the Westerlies in Mediterranean Central Chile during the last 2000 years: the Laguna Aculeo record (33 degrees 50 ' S). Quaternary International 87: 3-18.

Kirchner G. 2011. Pb-210 as a tool for establishing sediment chronologies: examples of potentials and limitations of conventional dating models. Journal of Environmental Radioactivity 102(5): 490-494.

Krishnaswami S, Lal D, Martin JM, Meybeck M. 1971. Geochronology of lake sediments. Earth and Planetary Science Letters 11(5): $407-414$.

Lane LJ, Kidwell MR. 2003. Hydrology and Soil Erosion, Santa Rita Experimental Range: 100 Years (1903-2003) of Accomplishments and Contributions. USDA Tucson, AZ, 92-100.

Lane LJ, Hernandez M, Nichols M. 1997. Processes controlling sediment yield from watersheds as functions of spatial scale. Environmental Modelling and Software 12(4): 355-369.

Legarda F et al. 2011. Inventory and vertical migration of Cs-137 in Spanish mainland soils. Journal of Environmental Radioactivity 102(6): 589-597.
Li RY, Yang H, Tang XY, Wu CY, Du MY. 2004. Distribution of Cs-137 and organic carbon in particle size fractions in an alumi-haplic acrisol of Southern China. Soil Science 169(5): 374-384.

Likar A, Omahen G, Lipoglavsek M, Vidmar T. 2001. A theoretical description of diffusion and migration of Cs-137 in soil. Journal of Environmental Radioactivity 57(3): 191-201.

Liu SW, Narentuya Xia BR, Chu GQ, Tian MZ. 2012. Using Pb-210(uns) and $\mathrm{Cs}-137$ to date recent sediment cores from the Badain Jaran Desert, Inner Mongolia, China. Quaternary Geochronology 12: 30-39.

Martin SC, Morton HL. 1993. Mesquite control increases grass density and reduces soil loss in southern Arizona. Journal of Range Management 46(2): 170-175.

Nearing MA, Nichols MH, Stone JJ, Renard KG, Simanton JR. 2007. Sediment yields from unit-source semiarid watersheds at Walnut Gulch. Water Resources Research 43(6) W06426. DOI:10.1029/ 2006WR005692.

Nichols MH. 2006. Measured sediment yield rates from semiarid rangeland watersheds. Rangeland Ecology and Management 59(1): 55-62.

Nichols MH, Anson E, Keefer T. 2014. Uncertainty in measuring runoff from small watersheds using instrumented outlet ponds. Transactions of the ASABE 57(3): 851-859.

NRCS, 2003. Soil Survey of Cochise County, Arizona, Douglas-Tombstone Part. NRCS, Washington, DC.

Osborn HB, Simanton JR, Renard KG. 1978. Sediment yields of rangeland watersheds. Proceedings of the 1 st International Rangeland Congress. Society of Range Management, Denver, CO, 329-330.

Osterkamp WR, Friedman JM. 2000. The disparity between extreme rainfall events and rare floods - with emphasis on the semi-arid American West. Hydrological Processes 14(16-17): 2817-2829.

Osterkamp WR, Toy TJ. 1997. Geomorphic considerations for erosion prediction. Environmental Geology 29(3-4): 152-157.

Polyakov VO et al. 2010a. Long-term runoff and sediment yields from small semiarid watersheds in southern Arizona. Water Resources Research 46 . DOI:10.1029/2009WR009001.W09512

Polyakov VO et al. 2010b. Runoff and erosional responses to a drought-induced shift in a desert grassland community composition. Journal of Geophysical Research - Biogeosciences: 115.

Quindos LS et al. 2006. Correction by self-attenuation in gamma-ray spectrometry for environmental samples. Journal of Radioanalytical and Nuclear Chemistry 270(2): 339-343.

Shakhashiro A, Tarjan S, Ceccatelli A, Kis-Benedek G, Betti M. 2012. IAEA-447: a new certified reference material for environmental radioactivity measurements. Applied Radiation and Isotopes $\mathbf{7 0}(8)$ : 1632-1643.

Sheppard PR, Comrie AC, Packin GD, Angersbach K, Hughes MK. 2002. The climate of the US Southwest. Climate Research 21(3): 219-238.

Terry JP, Lal R, Garimella S. 2011. Assessing the utility of $210 \mathrm{~Pb}$ geochronology for estimating sediment accumulation rates on river floodplains in Fiji. Singapore Journal of Tropical Geography 32(1): 102-114.

Turner LJ, Delorme LD. 1996. Assessment of Pb-210 data from Canadian lakes using the CIC and CRS models. Environmental Geology 28(2): 78-87.

Van Eaton AR et al. 2010. A novel application of radionuclides for dating sediment cores from sandy, anthropogenically disturbed estuaries. Marine and Freshwater Research 61(11): 1268-1277.

Wren DG, Davidson GR. 2011. Using lake sedimentation rates to quantify the effectiveness of erosion control in watersheds. Journal of Soil and Water Conservation 66(5): 313-322.

\section{Supporting Information}

Additional supporting information may be found in the online version of this article at the publisher's web site. 